\title{
Jackie Robinson, Jewish Icon
}

\author{
Rebecca Alpert \\ Temple University
}

\begin{abstract}
The story of Jackie Robinson's integration of baseball in 1947 provided Jews with a myth representative of their experience of assimilation into American society in the era following World War II. Popular Jewish accounts of this story, found in children's literature and adult fiction, essay and memoir, reveal three themes: identification with Robinson as a victim of oppression, idealization of Robinson as a heroic figure whose success announced the possibility of an end to all bigotry, and glorification of the role Jews played in bringing about Robinson's triumph. The ways in which Jewish writers tell this story reveal how the Jewish ideal of a special relationship between Blacks and Jews derived from drawing connections, based primarily in the Jewish imagination, between Jewish and Black experiences of integration and assimilation.
\end{abstract}

The literature about the relationship between African Americans and Jews in the twentieth century United States continues to grow. Most of this work has substantiated Jeffrey Melnick's insight that "Black-Jewish relations" is "a story told by Jews about interracial relations. ${ }^{1}$ In recent years scholars have used this insight to examine "Black-Jewish relations" through the lens of politics and in the world of music and film. ${ }^{2}$ One dimension that has yet to be looked at is

${ }^{1}$ Jeffrey Melnick, A Right to Sing the Blues: African Americans, Jews, and American Popular Song (Cambridge, MA: Harvard University Press, 1999), p. 4.

${ }^{2}$ The most recently published study of the political relationship between Blacks and Jews is Eric J. Sundquist, Strangers in the Land: Blacks, Jews, Post-Holocaust America (Cambridge, MA: Belknap Press of Harvard University Press, 2005). Jonathan Schorsch has written the definitive study of Blacks and Jews in early modernity, Jews and Blacks in the Early Modern World (Cambridge, UK: Cambridge University Press, 2004). And the Summer 2005 issue of Shofar places Black-Jewish relations in the context of other studies of Jews and race in America. Michael Rogin and Jeffrey Melnick did ground-breaking work 
how this Jewish fascination with African Americans played out in the world of sports.

\section{Identification: The Kinship of Hardship}

The desire to become American played a major role in defining Jewish experience in the first half of the twentieth century. Jews perceived themselves as outsiders and were concerned about antisemitism. As baseball functioned as "the national pastime" it provided an avenue of belonging. The popularity and fame of outstanding Jewish baseball players like Hank Greenberg helped make Jews feel at home in America. ${ }^{3}$ Jews of this era identified the struggles of Hank Greenberg in overcoming antisemitism as a ball player in the late 1930s with the struggle Robinson faced. Newspaper columnist Jack Newfield noted that most of his older relatives believed that Hank Greenberg suffered in the same ways Robinson did. While Newfield believed that antisemitism against Greenberg was real, but not of the same order as what Robinson experienced, he saw the connections: "Kinship between Blacks and Jews would play a big role in my life. And this alliance between Robinson and Greenberg was probably my first awareness of this kinship of hardship."

In his 1948 autobiography, Jackie Robinson noted his connection to Greenberg, whom he met when they played one game on opposing teams in the 1947 season, Greenberg's last and Robinson's first. Greenberg was playing first base, and he and Robinson collided accidentally when Robinson was running the base path. He called Greenberg's words to him on that occasion

on Jews and Blacks in film and music respectively, Blackface, White Noise: Jewish Immigrants in the Hollywood Melting Pot (Berkeley: University of California Press, 1996) and A Right to Sing the Blues: African Americans, Jews, and American Popular Song. I'm indebted to their insights about Jewish perceptions of our relationship to African Americans in popular culture. While African Americans have less interest in this story, they are also doing important critical work. V. P. Franklin et al., eds., African Americans and Jews in the Twentieth Century: Studies in Convergence and Conflict (Columbia and London: University of Missouri Press, 1998) addresses the conflicts from both Black and Jewish perspectives. We are also beginning to see works by and about African American Jews whose stories are almost always ignored when Black-Jewish relations are discussed, e.g., Diane Tobin, Gary A. Tobin and Scott Rubin, In Every Tongue: The Racial and Ethnic Diversity of the Jewish People (San Francisco: Institute for Jewish and Community Research, 2005).

${ }^{3}$ William M. Simons, “The Athlete as Jewish Standard Bearer: Media Images of Hank Greenberg," Jewish Social Studies, Vol. 44 (Spring 1982): 95-112.

'Jack Newfield, Somebody's Gotta Tell It: The Upbeat Memoir of a Working-Class Journalist (New York: St. Martin's Press, 2002), p. 36. 
"the first real words of encouragement I received from a player on an opposing team," suggesting that Greenberg was "sincere because I heard he had experienced some racial trouble when he came up. I felt sure that he understood my problems."5 Greenberg also suggested that the connections between himself and Robinson were about a common bond over racism and antisemitism. In his autobiography he comments in hindsight, "Jackie had it tough, tougher than any ballplayer who ever lived. I happened to be a Jew, one of the few in baseball, but I was white. . . . But I identified with Jackie Robinson. I had feelings for him because they had treated me the same way. Not as bad, but they made remarks about my being a sheenie and a Jew all the time."

The story of the one meeting between Greenberg and Robinson achieved legendary status in Jewish writing, although it is rarely mentioned in general scholarship about Robinson. The theme finds expression in Pete Hamill's Snow in August. Not himself a Jew, Hamill tells the story from the perspective of a young Christian boy in Brooklyn, Michael, who befriends a rabbi who had come to the United States from Prague after the Holocaust. As the Rabbi teaches Michael about Judaism, Michael helps introduce him to baseball. Robinson's story was what made the rabbi interested in baseball, because it held out hope to him of America's promise. The rabbi worried when Robin-

5Jackie Robinson, Jackie Robinson: My Own Story (New York: Greenberg, 1948), pp. 146-7. Robinson maintained strong connections with Jews throughout his adult life, supported Jewish causes, and subscribed to the theory that there was indeed a special connection between Jews and Blacks that united them. In "The Jackie Robinson I Remember," Roger Kahn related telling Robinson the story of being called "Izzy" (a "not terribly subtle code word for Jew") at a prep school he attended. He describes Robinson's response: "When I told Jackie Robinson that story on a slow train through Alabama 44 springs ago, his eyes moistened with pain for that touchdown-scoring, wounded little kid. We barely knew each other, but to use George Washington's noble phrase, Jackie Robinson gave 'bigotry no sanction.' He hated anti-Semitism just as he hated prejudice against Blacks-without qualification and from the gut" (Journal of Blacks in Higher Education, Vol. 14 [Winter 1996/1997]: 89). According to Kahn, Robinson would tolerate no slurs against anyone; he would even express his contempt if someone so much as told a "Polish joke." He truly empathized with those who experienced prejudice of any kind (Roger Kahn, interview by the author, December 10, 2005). Robinson saw Jews both as supporters of civil rights and as good role models for Blacks to emulate in their struggle for full equality in the United States. He defended Jews against charges of racism, even in the 1960s when it became extremely unpopular in the black community to do so. Arnold Rampersad makes this clear in his definitive biography, Jackie Robinson: A Biography (New York: Alfred A. Knopf, 1997).

${ }^{6}$ Hank Greenberg, Hank Greenberg: The Story of My Life, ed. Ira Berkow (New York: Times Books, 1989), p. 191. 
son was in a slump and concluded: "In America he [Robinson] is new. Just like me." Because he is hated, "Jackie Robinson is a Jew. You see?"7 Late in the novel, Michael and Rabbi Hirsch go to a Dodgers game together. Of course, it is the game they played against the Pittsburgh Pirates and Hank Greenberg. Some white fans make antisemitic comments about Greenberg, and a fight ensues in the stands between the black fans and some men from a local labor Union who defend Greenberg against the bigots who made the remarks. ${ }^{8}$

Robinson's story was something that Jews identified with: as he was attacked and persecuted, so were we. Jewish leaders of the era subscribed to the "unitary theory of bigotry" This theory claims that in order to end one form of oppression, all oppression will have to be eradicated. So a fight against antisemitism would by definition include working against all forms of racial and ethnic injustice, and anti-racist activities would help put an end to antisemitism. What these stories fail to reveal, however, is that while baseball's integration accurately reflected opportunities for Jews in America to assimilate, for Blacks the story was quite different.

In 1947 a major Hollywood motion picture, Gentleman's Agreement, based on the novel by Laura Hobson, depicted the range of antisemitic attitudes and behaviors that Jews experienced at the time. ${ }^{9}$ Gregory Peck played a journalist (Phil Green) posing as a Jew to write an article about antisemitism. Green and his Jewish friend (a soldier returned from the war) faced barriers in housing, employment, and social connections. Green's son Tommy was beaten up and taunted with racial slurs. His secretary, a Jew who changed her name to get a job, illustrated the problems faced even by Jews who tried to hide their identities. The film was poignant and well received and contributed to the process that marked the beginning of the end of publicly acceptable antisemitism of the type the film illustrated. The message was clear: if no one could really tell that Gregory Peck was not, in fact, a Jew, then there was no reason to hate. Seth Forman characterized the point succinctly in his analysis of the film: "Tolerance is necessary because we're all the same." ${ }^{10}$

Gentleman's Agreement, which depicted antisemitism as a problem that was very much alive, appeared at a time when antisemitism was in fact de-

${ }^{7}$ Pete Hamill, Snow in August (New York: Warner Books, 1997), p. 322.

${ }^{8}$ Hamill, Snow in August, p. 375.

${ }^{9}$ Elia Kazan, Gentleman's Agreement (Twentieth Century Fox, 1947).

${ }^{10}$ Seth Forman, Blacks in the Jewish Mind: A Crisis of Liberalism (New York: New York University Press, 1998), p. 26.

Vol. 26 , No. 2 • 2008 
creasing in America. World War II brought about major changes in the way the United States would deal with the problem of minority groups. Fighting Hitler and fascism abroad shed a new and negative light on segregation and hatred at home. How could we as a society object to Hitler's racist policies against the Jews and other groups in Europe if we practiced the same kind of racial politics against Jews, Blacks, and others right here in America? The war made it obvious to many, especially the young men and women returning from the war, that change was necessary. Before the war, racial and ethnic segregation was the norm, and bigotry in the form of verbal slurs and separate spaces was not only tolerated but presumed and legally sanctioned. World War II marked an end to virulent and public antisemitism. While Jewish anti-defamation groups maintained a defensive posture, they were also made resolute by the lessons learned from the destruction of European Jewry to begin public campaigns to mobilize public opinion and counter stereotypes, working for legislation against bigotry and fighting discrimination in the courts.

But the fight against anti-Black racism was just beginning. The idea that we're all the same was not at all the message of another Hollywood film, The Jackie Robinson Story. ${ }^{11}$ Starring Jackie Robinson himself, this film was made in 1950, three years after Gentleman's Agreement won the Oscar and Robinson played his first game in major league baseball. The film told the story of Robinson's life and the racism he encountered in the process of becoming the first African American since 1889 to play in the major leagues. The film portrayed Robinson's experiences as a ball player dealing with Jim Crow laws in the South and illustrated some of the racial incidents he faced in his first few years in the major leagues, including death threats and intimidation by fans. But the Hollywood version of Robinson's story omitted many of the injustices he experienced, including a court martial when he was in the U.S. Army during World War II for refusing to move to the back of the bus, even though the Army had by then made segregated seating illegal on its vehicles. And the movie ends with Robinson's testimony before the House Un-American Activities Committee, in an effort to underscore his allegiance to this country where he was now allowed to play ball with whites and where the loyalty of black citizens was being questioned by anti-Communists. While The Jackie Robinson Story tried to present a similar message of tolerance as Gentleman's Agreement, it was clear that tolerance for Jews and Blacks meant two different things. Jews were evolving into a new status that would make them equal to whites; Blacks

${ }^{11}$ Alfred E. Green, The Jackie Robinson Story (Eagle Lion Films, 1950). 
were seen as different. Jews could assimilate, but there were conditions placed on Robinson's acceptance as a black man in a white world. ${ }^{12}$

These films illustrate the different fates of Blacks and Jews in post World War II America. What Jews saw in these two stories was a connected fate. Jews wanted to assume that their successes were also possible for African Americans as symbolized by Jackie Robinson and the integration of baseball. They saw in America the potential for tolerance based on their own experiences and did not discern the real difference between anti-Black racism and antisemitism.

\section{Robinson as a Jewish Hero}

Comparing these films gives us a sense of why Jackie Robinson's story was read by Jews as symbolic of the potential promise of equality in America. Jewish versions of this story reflect the process of our own assimilation into American society and reveal much about our anxiety over belonging. Jackie Robinson's success functioned as a proof text for our own shift in racial identity in the United States.

As Jews saw it, if Jackie Robinson could integrate Major League baseball, then Jews would truly be welcome in America. As Matthew Frye Jacobson and others argue, Jews became white in twentieth century America through a process that began with the restrictions on European immigration in 1924 and continued due to various redefinitions of Caucasian identity and in response to Hitler's antisemitic racism. ${ }^{13}$ But the process took shape gradually, and Jews remained insecure in America in 1947. They sought validation and found proof for it in Robinson's triumph.

Identifying with Robinson as an American hero also enabled Jewish men to overcome the stereotype of effeminacy with which they were often associated. The Jewish versions of the Robinson saga, while narrated by both men and women, are always about men and boys. Jeffrey Melnick argues that the subtext of most discussions of Black-Jewish relations is masculinist at least, and alternatingly homophobic and homoerotic as well. ${ }^{14}$ This is certainly a

\footnotetext{
${ }^{12}$ The story of the contrast between the fate of Jews and Blacks at this historical juncture is portrayed more directly in a 1947 Hollywood film set in the world of boxing, Body and Soul. See Rogin, Blackface, White Noise, p. 216.

${ }^{13}$ Matthew Frye Jacobson, Whiteness of a Different Color: European Immigrants and the Alchemy of Race (Cambridge, MA: Harvard University Press, 1998), chapter 5; and Karen Brodkin, How Jews Became White Folks and What That Says About Race in America (New Brunswick, NJ: Rutgers University Press, 1998).

${ }^{14}$ Jeffrey Melnick, "Some Notes on the Erotics of 'Black-Jewish Relations," Shofar: An Interdisciplinary Journal of Jewish Studies, Vol. 23, No. 4 (Summer 2005): 9-25.
} 
plausible reading of the story of Jewish men and Jackie Robinson, especially the tales of young male bravery we encounter in children's stories.

In 1947 Jews still experienced themselves as outsiders. Ivan Hametz, author of an essay about what Robinson meant to him as a child, comments that as a ten-year-old, he "needed a surrogate champion. As a Jew, vulnerable to mob mentality and group oppression, I discovered Jackie Robinson. In his quest for recognition and respect, he fought for us." ${ }^{15}$

Jews saw Jackie Robinson as someone who could battle on their behalf against antisemitism. In Joanne Rocklin's children's book Strudel Stories, Willie is an American Jew whose grandchildren ask him to "tell us about baseball games ... the great game of 1947: the first time you saw Jackie Robinson play in the major leagues." ${ }^{16}$ Instead, Willie tells them a different but related story, about a friend of his named Leon who, like Pete Hamill's character Rabbi Hirsch, was a Holocaust survivor who arrived as a boy in Brooklyn in 1948. To help acculturate his new friend, Willie introduced him to the story of Jackie Robinson. When Leon is having trouble with the transition to becoming an American, Willie gets the idea that he will teach him to play stickball so that, like Robinson, he would be accepted. As he came to the idea, a car went down the street, and " $t]$ he headlights lit up Jackie Robinson's picture on the wall. And I swear, right at that moment, Jackie Robinson winked at me., ${ }^{17}$ In the Jewish imagination, Robinson represented the hope that America was a place where those who were persecuted could fight to overcome their detractors, unlike the Jews in the Holocaust. Robinson's example made it possible to imagine that Holocaust survivors would have a second chance here.

In another children's book, Thank You, Jackie Robinson by Barbara Cohen, Robinson was the magical figure who helped a young Jewish boy deal with the loss of his father. Sammy, aged ten, made friends with Davy, the sixty-year-old black cook in Sammy's mother's restaurant in New Jersey. They bonded over their mutual love of the Dodgers and Jackie Robinson, talking about and going to games together. Sammy also learned about courage by going by himself to a game and getting Robinson's autograph for Davy when he is in the hospital, dying of heart failure. For a while after Davy's death, Sammy is so grief strick-

${ }^{15}$ Ivan Hametz, "A Ten-Year-Old Dodger Fan Welcomes Jackie Robinson to Brooklyn," in Joseph Dorinson and Joram Warmund, eds., Jackie Robinson: Race, Sports and the American Dream (Armonk, NY: M.E.Sharpe, 1998), p. 68.

${ }^{16}$ Joanne Rocklin, Strudel Stories (New York: Delacorte Press, 2000), p. 84.

${ }^{17}$ Rocklin, Strudel Stories, p. 106. 
en that he can't pay any attention to the Dodgers. But eventually he overcomes his sadness, and the book closes with Sammy reflecting on a hit by Robinson he hears described on the radio:

I only know that Jackie Robinson had saved me once again. In my mind's eye I could see him tearing around the base paths with more speed than any other man in baseball. I could see him ... in my mind, where nothing ever dies. I can see him still, to this very day ... running in a brand new baseball game that will never, never be over. ${ }^{18}$

Jewish idealization of Jackie Robinson as a protective figure finds its fullest expression in Jay Neugeboren's novel, Before My Life Began. The protagonist in this novel, Davey Voloshin, is growing up in Brooklyn in the 1940s. He is the nephew of a prominent Jewish racketeer and is expected to follow his father, who runs numbers for the syndicate, into Uncle Abe's business. ${ }^{19}$ Throughout the text, the narrative of Robinson's life cross-cuts Davey's story; Neugeboren narrates Robinson's biography in great detail in several passages, each several pages long, a story within a story. For Davey, Robinson is the figure he looks up to and who will serve as a touchstone when Davey needs support and encouragement.

Anytime Davey experienced adversity or needed inspiration, he would think about Jackie Robinson. Davey decided "to bore my thoughts into his [Robinson's] skull so I could feel exactly what he was feeling." ${ }^{20}$ When talking to his father, whom he loved but who made him uncomfortable because he was so weak, his mind would wander to some event in Robinson's life. When he kissed his first girlfriend for the first time, he imagined Jackie and his wife Rachel kissing. In the middle of his wedding night he told his already pregnant wife about Jackie and Rachel naming their third child David and how important it was to him since that was his name, too. ${ }^{21}$ When Uncle Abe is killed in a gangland murder, Davey wonders whether to avenge his death. He thinks to himself, "what would Jackie do in my shoes?" When he decides to kill his uncle's killer, he "feels Jackie's rage surging through his own body." 2

As a result, Davey flees Brooklyn, changes his identity, and becomes Aaron Levine. We meet up with him a few years later in the South where he is teaching as part of Freedom Summer. He tells the black family with whom

\footnotetext{
${ }^{18}$ Barbara Cohen, Thank You, Jackie Robinson (New York: Beech Tree, 1974), p. 125.

${ }^{19}$ Jay Neugeboren, Before My Life Began (New York: Simon \& Schuster, 1985), p. 66.

${ }^{20}$ Neugeboren, Before My Life Began, p. 88.

${ }^{21}$ Neugeboren, Before My Life Began, p. 189.

${ }^{22}$ Neugeboren, Before My Life Began, p. 313.
} 
he's staying of seeing Robinson play and adds: "When Jackie took the field ... it reminded us all that it was our birthright to be free." ${ }^{23}$ Aaron is living a contented life with a new wife, Susan, children of hers from a previous marriage, and two children of their own, in Northampton, Massachusetts until Susan leaves him for Lucius, the young black man Aaron brought north from his summer in Mississippi. This episode contrasts Jewish and Black masculinity in relation to the white, Christian woman. Aaron loses out to Lucius for Susan's affections because he refuses to come to terms with his past and is always hiding his true feelings from her.

Soon after they leave, Aaron hears the news that Jackie Robinson has died. This news precipitates a flood of emotions that brings Aaron's story to a climax. He finds himself distraught because he is actually crying for Robinson when he couldn't cry for his father or uncle. ${ }^{24}$ He realizes that what he's been learning about grief in the adult education class at the synagogue he's joined, how the Mourner's Kaddish is "a prayer for the living in which we declare our faith that life goes on," 25 is a key to understanding his own problems. Aaron's solution is to tell his children the story of Jackie Robinson, which in turn awakens a need to reconnect to his past.

In the novel's final scene, Aaron takes his sons to Robinson's funeral in New York. They are going to Harlem to the viewing, "to see Jackie. To say goodbye." ${ }^{26}$ On the way there, he explains to his sons that "there are some people who just hate Jews because they like to hate people. The way people hate Blacks" ${ }^{27}$ to make the connection between their lives and Robinson. He tells them that Robinson was special. Not that he hit more home runs or stole more bases than others, but because he was the energy behind the team. Finally, Aaron decides that after the funeral he will take the boys back to Brooklyn, and walk the streets of his childhood with them, making his story complete as well.

In his portrait of Davey/Aaron, Neugeboren illustrates the ways in which Jews found hope and promise for equality and acceptance through the symbolic presence of Jackie Robinson. For Aaron, loving Robinson gave him the strength to love himself, and to accept himself as a Jew. Robinson's powerful

\footnotetext{
${ }^{23}$ Neugeboren, Before My Life Began, p. 379.

${ }^{24}$ Neugeboren, Before My Life Began, p. 376.

${ }^{25}$ Neugeboren, Before My Life Began, p. 377.

${ }^{26}$ Neugeboren, Before My Life Began, p. 396.

${ }^{27}$ Neugeboren, Before My Life Began, p. 389.
} 
masculinity gave him someone to emulate in his quest to be a man. Robinson's triumph over imperfections and tragedies gave Aaron the courage to believe that he, too, could achieve wholeness.

As Jews proclaimed and identified with the heroism inherent in Robinson's story, they also proclaimed and identified with his strong masculine identity. Robinson's ability to withstand bigotry as part of Rickey's great experiment, and later his assertive response to those he thought were not playing fair, were role models for Jewish men who were often perceived to be weak and unable to fight back themselves. Robinson's daring on the field, exemplified by the frequency with which he stole home, was another aspect of this strong masculinity that appealed to the Jewish men who idolized him..$^{28}$

In these stories Jackie Robinson is the hero who gives Jewish men and boys the courage to claim their full status as Americans. These writers saw Robinson as their champion. The stories reveal a deep tension the Jews of this era experienced. They feared antisemitism and remained uncomfortable with American identity. Through Robinson's story they found a vehicle to express their yearning for acceptance into American society.

\section{The Jewish Fight against Bigotry}

Yet Jewish writers don't only reflect Jewish inadequacy and desire; they also describe a secure community in Brooklyn that welcomed Jackie Robinson. One factor in Branch Rickey's plan to integrate baseball was to conduct his "great experiment" in a city that would be hospitable. ${ }^{29}$ Although Brooklyn had its share of conservatives, Jews who identified as liberal and supportive of integration made up one-third of the borough's population. And Rickey knew that they would welcome this move. ${ }^{30}$ It was important for the Jews of Brooklyn to see themselves creating a hospitable environment for Robinson's entry

${ }^{28}$ Of course, the relationship between the black male athlete and the white male spectator includes many more complex variables than simply a story of admiration. For a thoughtful treatment, see Daniel Rosensweig, Retro Ball Parks: Instant History, Baseball, and the New American City (Knoxville: University of Tennessee Press, 2005), chapter 6.

${ }^{29}$ There is no doubt that Rickey deserves credit for integrating baseball. Recent scholarship has recognized Robinson's agency, seeing him less as Rickey's "project" who agreed to "turn the other cheek" as Rickey demanded, and more as a race man who had his own powerful motivations for accepting the role as a pioneer (Glenn Stout et al., Jackie Robinson: Between the Baselines [San Francisco: Woodford Press, 1997], p. viii).

${ }^{30}$ Carl E Prince, Brooklyn's Dodgers: The Bums, the Borough, and the Best of Baseball 1947-1957 (New York: Oxford University Press, 1996).

Vol. 26 , No. 2 • 2008 
into baseball, enabling them to participate vicariously in an event that would revolutionize race relations in the United States. Fighting against racism also helped the Jews maintain their identity in the face of assimilation. The dream of equality that the enlightenment had promised had finally come to pass. But the bargain of the enlightenment came at a price: for individual freedom, Jews had to struggle to maintain their cultural identity. In exchange for equality, Jews were expected to assimilate. One way Jews could justify their existence as a distinct cultural group was by fighting for the rights of others. As Murray Friedman, a long-time student of Black-Jewish relations, suggested, "work for a society in which economic disadvantage and intolerance would have no place became a religio-cultural obsession." 31

In a sermon in 1997 to commemorate the $50^{\text {th }}$ anniversary of Robinson's entrance into the majors, Rabbi Corey Weiss remarked,"I doubt though that even Branch Rickey could have foreseen the way Jewish fans embraced Jackie Robinson." He called Robinson and Rickey "lamed-vavnicks," a reference to the thirty-six people, who, in Jewish tradition, are quietly responsible for making the world a better place. ${ }^{32}$ Rabbi Jonathan Perlman commented, "A lot of Jewish people ... grew up worshiping them as heroes. Robinson took a great deal of abuse.... The Brooklyn Dodgers and the fans stood behind him." ${ }^{33}$ For Ivan Hametz's father, a Greek Jewish immigrant, the integration of baseball was "what we were fighting for in World War II. Justice."

Jews became Brooklyn Dodger fans because this was the team that stood against bigotry by integrating baseball. When writer Ted Solotaroff adopted the Dodgers as his team, one of the main reasons was that he saw them as "the Jews of baseball," and the signing of Robinson was central to that perception. To him, Jackie Robinson was a Jew: "an alienated artist in baseball pants." Novelist Alan Lelchuk saw Robinson as he understood the status of Jews, as insiders and outsiders at the same time. To him Robinson was "a baseball hero and defiant conscience. For Dodger fans, and for that boy [Lelchuk himself],

${ }^{31}$ Forman, Blacks in the Jewish Mind, p. 26.

${ }^{32}$ Corey Weiss, "Sermon: Jackie and Branch," Congregation Beth Shalom Rodfe Zedek, Connecticut, 22 October 1999.

${ }^{33}$ Melody Wilensky, "For Jewish Fans, Baseball's Still the Name of the Game," The Jewish Advocate, 28 October 1999, 189.43, A1.

${ }^{34}$ Hametz, "A Ten-Year-Old Dodger Fan Welcomes Jackie Robinson to Brooklyn," p. 66.

${ }^{35}$ Ted Solotaroff,"Fan as in Fantasy," Tikkun, Vol. 5, No. 3 (May/June 1990): 20(2). 
he was an odd member of the family, at the same time that he was the stranger in the native game." 36

As cultural critic David Horowitz commented in his memoir, after 1947 "no conscientious progressive could be a Yankee fan." ${ }^{37}$ Author Peter Levine's father took him to his first game in 1956, the year of his bar mitzvah, and told him how proud he was "to live in a place that fielded baseball's first integrated baseball team." ${ }^{38}$ Signing Jackie Robinson elevated the moral status of the whole Dodger team and organization, and trading Jackie Robinson lowered it. This is reflected in a 1991 episode of the TV series "Brooklyn Bridge" about a Jewish family in Brooklyn in the 1950s. Phyllis, mother of the young protagonist Alan Silver, declares the trade to be "not kosher," while Alan and his friends sit in mourning as they live out their first experience of the evil that can be perpetrated by the powerful. ${ }^{39}$

My inspiration for writing this story is that my own values as an American Jew were shaped by the affection and respect I imbibed through my mother's teachings about Jackie Robinson. I had not thought much about how important baseball and Jackie Robinson were to me in terms of my religious identity until I was interviewed by Bill Freedman for his book of oral histories, More Than Just a Pastime. When the book was published and I had an opportunity to read and reflect on what I said, it became clear to me that baseball was part of the religious legacy I inherited, as I related this story to Bill:

[T] hat deep connection between the Dodgers and my mother and me-I'll never forget that. The great moral allegory of course was Jackie Robinson. ... There was a whole ethos of goodness associated with the Dodgers because they were integrated. The Yankees may have won more often, but the Dodgers-my mother made sure I understood this - had the higher moral ground. ${ }^{40}$

The story about Robinson and baseball's integration served as a powerful moral influence throughout my life. The message I got both from my family

${ }^{36}$ Alan Lelchuk, Brooklyn Boy (New York: McGraw-Hill, 1990), p. 97.

${ }^{37}$ David Horowitz, Radical Son: A Generational Odyssey (New York: The Free Press, 1997), p. 57.

${ }^{38}$ Peter Levine, "Father and Son at Ebbets Field," in Dorinson and Warmund, eds., Jackie Robinson: Race, Sports and the American Dream, p. 63.

${ }^{39}$ Gary David Goldberg and Brad Hall, Brooklyn Bridge (CBS TV, 12/11/1991), "Where Have You Gone, Jackie Robinson."

${ }^{40}$ William Freedman, More Than a Pastime: An Oral History of Baseball Fans (Jefferson, NC: McFarland \& Company, 1998), p. 132. 
and from the Reform synagogue I attended as a child in the 1950s was that social justice is a primary Jewish value. To that end, Jews have an obligation to make sure we not only secure our own rights, but we must also overcome our own prejudices, root out the causes of injustice, and pass this lesson down through the generations.

One explanation about why Jews were so deeply committed to fostering the legal rights and integration of African Americans is that it was a perfect expression for the ideal of justice that is deeply ingrained in Jewish textual tradition and in the theology of a just God who will deliver the oppressed from bondage. Jews tell the biblical story of the Exodus from Egypt each year during the Passover Seder to ensure that this ancient tale of Jewish liberation passes from one generation to the next. The fact that African American Christians, especially during the time of enslavement, saw the Exodus narrative as a model of liberation serves to validate this connection.

It is not surprising that Ken Burns would use this theme in his epic documentary on baseball as the climax of the pivotal segment on Jackie Robinson. Burns closes his retelling of Robinson's story with a voice-over about a Jewish family celebrating Passover in Brooklyn on April 15, 1947, when Robinson played his first regular season game for the Brooklyn Dodgers. The narrator says:

That evening, at $157450^{\text {th }}$ Street in the Borough Park section of Brooklyn as the family sat down for its Passover Seder, the youngest member asked the traditional question, "Why is this night different from all other nights?" and replied, "Today, the first black American baseball player entered the major leagues." ${ }^{41}$

Instead of telling the story of Jewish liberation, this Jewish family substitutes the story of African-American liberation as exemplified by Robinson. Jews take pride in the connection between the ancient emancipation of the Hebrews and bringing an end to segregation in America. We find repeated references to this connection in scholarly accounts, memoir, journalism, and fiction about baseball and the Jews.

The Passover theme of telling this story again and again was also echoed by Jack Newfield, who says in his memoir: "His [Robinson's] first season be-

${ }^{41}$ Ken Burns, Baseball (TV Mini Series, 1994). Burns was not concerned with the fact that the Passover Seder did not correspond with Opening Day that year, but that young Henry Foner, from whom he heard this story, was watching Robinson play on April 9 for the Montreal Royals in an exhibition game with the Dodgers the day before Rickey made the announcement that Robinson would be joining the Brooklyn team (Henry Foner,"Mah Nishtanah," in Dorinson and Warmund, eds., Jackie Robinson: Race, Sports, and the American Dream," p. 71). 
came my Passover story, a fable of freedom, to be retold again and again to keep the memory alive." 42

Jay Neugeboren's novel also makes this connection to Passover in the closing scene:

What Aaron wants to do, he knows, is simply-yet again - to tell the story of Jackie's life to his son. He smiles. Would his father, or his father's brothers, be pleased with him? At Passover, when the children ask the reason for certain rituals ... the father answers by telling the story of going forth from Egypt. ${ }^{43}$

Jules Tygiel, a Jew whose classic book on the integration of baseball makes no other references to his heritage, closes his final chapter with the following thought: "As my friend and fellow historian Steve Riess has commented, the Jackie Robinson story is to Americans what the Passover story is to Jews: it must be told to every generation so that we never forget." ${ }^{44} \mathrm{He}$ goes on to suggest that Robinson's story is indeed "of biblical proportions," that he was Moses in the early years, "leading his people out of the wilderness into the Promised Land." ${ }^{45}$ He also suggests that at the end of his life Robinson could be compared to Moses in another respect. Tygiel is aware that the stories of the Hebrews in the Bible and Blacks in America had different endings. Echoing the phrasing of Martin Luther King, Tygiel remarked that Robinson "had gone to the mountaintop, but that neither he nor his people would be allowed to enter the Promised Land." 46

In the fight for integration, Blacks became surrogates for Jews in the Jewish mind, and in this role Jackie Robinson was indeed a Jew. While this connection worked for a time, it held within itself an inherent contradiction. Jews fighting for the full integration of African Americans would find themselves having to make a difficult choice between maintaining the Jewish neighborhoods that also sustained the Jews' cultural identity and local communal structures from grocery stores to synagogues, and supporting integration, which would ultimately destroy this communal structure. ${ }^{47}$ In 1947 that contradic-

${ }^{42}$ Newfield, Somebody's Gotta Tell It, p. 40.

${ }^{43}$ Neugeboren, Before My Life Began, p. 389.

${ }^{44} J u l e s$ Tygiel, Baseball's Great Experiment: Jackie Robinson and His Legacy, expanded ed. (New York: Oxford University Press, 1997), p. 345.

${ }^{45}$ Tygiel, Baseball's Great Experiment, p. 346.

${ }^{46}$ Tygiel, Baseball's Great Experiment, p. 350.

${ }^{47}$ Deborah Dash Moore, At Home in America: Second Generation New York Jews (New York: Columbia University Press, 1981). 
tion was not yet clear to the Jews of Brooklyn who were passionately committed to integration. Robinson gave young Jews their first experiences of seeing Blacks in their full humanity as kindred spirits. Yet the cracks in this glorious identification that became obvious in later decades made it difficult for some writers to address the story only through the lens of nostalgia. Ira Glasser, former head of the New York branch of the ACLU, describes how he remembers Robinson in a condolence letter he sent to Robinson's widow in 1972:

I am 11 years old, and Jackie Robinson is on his way to his greatest season. I am in Ebbets Field, and everywhere around me .... are Negroes. I am white and Jewish and in East Flatbush where I live there are no Blacks. The only Blacks I see are cleaning women (called girls), janitors and an occasional drunk. None are real to me. But there I am in Ebbets Field screaming together with Blacks because ... Jackie has forced the opposing pitcher to balk home a run.... A white boy is embracing a middle-aged black man while beer and sweat and cigar ashes mingle with the joy. There was community that day ... between white and black in Ebbets Field, a common meeting ground in a society that had successfully banished all other common meeting grounds ... ${ }^{48}$

Ebbets Field was the place where Blacks and Jews could come to know one another as equals. For liberal Jews, this connection was deeply meaningful, and Jackie Robinson was its source. The connection Robinson exemplified contradicted the reality that Glasser came to understand later, that even in the 1940s the Jews who welcomed Robinson also perceived Blacks as an impoverished servant class of domestics, janitors, and drunks. Yet Glasser, like other Jewish writers, still clings to the symbol of Robinson overcoming those tensions.

Poet Joel Oppenheimer's powerful description of opening day in 1947 and the ways this identification with Robinson functioned in the Jewish imagination also reflects some of the difficulties in sustaining the myth:

in $1947 \mathrm{i}$ was seventeen, and that was very young in those days. $\mathrm{i}$ stood in the stands the day he came to brooklyn and i was surrounded by black faces. that never happened to me before. from somewhere near me $i$ heard a voice from childhood, a jewish tailor. yankel, yankel, yankel [Yiddish for Jackie] he yelled, as hard as his neighbors shouting jack, jack, jack. that is very hard to believe this year when his children live in forest hills. ${ }^{49}$

${ }^{48}$ Ira Glasser, New York, NY, Condolence note, to Rachel Robinson, October 26, 1972, Jackie Robinson Papers, Manuscript Divison, Library of Congress.

${ }^{49}$ Joel Oppenheimer, The Wrong Season (Indiannapolis: Bobbs-Merrill, 1973), p. 156. 
The mythologized identification between Jews and Blacks Jackie Robinson exemplifies would seem much more complicated when Oppenheimer recalled them in the 1960s, as the reference to "forest hills" evokes the tensions between Blacks and Jews that reached a climax in that decade. It was no longer possible when Oppenheimer wrote this for Jews to pretend that the groups shared a similar fate in America.

\section{Conclusion}

Despite the differences in how these stories developed, these novels, essays, sermons, and memoirs reflect a consciousness in the Jewish world of a connection to Robinson that found communal expression again on the fiftieth anniversary of Robinson's entry into the major leagues. In 1997, Jewish organizations took the opportunity to celebrate that jubilee year with conferences and exhibits that reflected how much Robinson meant as a symbol of the fight against bigotry and for acceptance that linked Blacks and Jews together. The Simon Wiesenthal Center's Museum of Tolerance created a traveling exhibition, "Stealing Home: How Jackie Robinson Changed America." Its goal was to show how Robinson, in breaking the color line and in the rest of his life, was a model for tolerance. The exhibit traveled around North America and was displayed at many Jewish community centers, synagogues, and Jewish Halls of Fame. The Wiesenthal Center also entered a float in the Tournament of Roses Parade that year that depicted Robinson "in a Dodgers uniform sliding to steal a base, flanked by a giant baseball inscribed with his name, a ribbon festooned with the names of his college and minor league teams, and the names of the sponsoring Wiesenthal Center and its Museum of Tolerance." ${ }^{50}$ The many sermons, books and events that Jews produced during the Robinson jubilee make it clear that the myth of Jackie Robinson has maintained resonance for American Jews.

Every day when I drive to work in a predominantly African American neighborhood, I pass a large mural of Jackie Robinson stealing home. It is a good reminder that as Jews we are intruders on the story that rightly belongs to the black community. We borrow it because it is about how we imagine ourselves. While this appropriation of Robinson's story is troubling, it is also important to understand the powerful impact Robinson had on the Jewish community. Robinson was not only a model for Blacks, but represented Jewish values for justice and in opposition to bigotry.

${ }^{50}$ Tom Tugend, "Wiesenthal Center Sponsors Display in Rose Bowl Parade," Jewish Telegraphic Agency, 24 December 1996, p. 13. 
The result of my research has been to contextualize my experience in a larger story of Jewish assimilation, but also to validate what I learned from my mother: Jackie Robinson is a Jewish hero whose story teaches us about the role we must all play in the struggle for freedom, the importance of working for justice and equality, and the capacity of one individual to create change in society by standing up for his rights. Whenever Passover occurs around April 15, the day Jackie Robinson played his first game in the Major Leagues, our Seder will include some part of his story, so his legacy can be passed on. Robinson wasn't Moses. But he was Jackie Robinson: a man who made a critical contribution in the quest for freedom and justice in America. 